\title{
PID AND FUZZY CONTROLLING THREE PHASE ASYNCHRONOUS MACHINE BY LOW LEVEL DC SOURCE THREE PHASE INVERTER
}

\author{
Erol Can, H. Hüseyin Sayan
}

Original scientific paper In this study, a three-phase asynchronous motor driven by a broad-based system is described. So, mathematical model of converter, sinus pulse width modulation for the three phase inverter, and mathematical model of three-phase asynchronous motor have to be utilized in order to establish the system. After creating such a system, Fuzzy Logic and PID controllers are focused in order to get satisfactory results which are short settling time of rotor speed, low harmonic and short settling time of high phase current. Created mathematical models are run at the MATLAB Simulink. Direct voltage is applied to converter input. This voltage is represented by a renewable energy source that could be obtained from solar energy source. The direct voltage is lower than the peak of the alternating voltage. The alternating voltage is obtained from output of the inverter to drive the induction motor. Firstly, resistive (R) and inductive (L) loads are driven. Secondly, three-phase asynchronous motor (ASM) is driven with the low direct voltage. After that, simulation results are given in order to demonstrate performance and effectiveness of the proposed system.

Keywords: Fuzzy Logic; inverter; microcontroller; PID (proportional-integral-derivative); pulse-width modulation

\section{PID i neizrazito upravljanje trofaznim asinhronim motorom pomoću trofaznog izmjenjivača slabe istosmjerne struje}

Izvorni znanstveni članak

U ovom se radu opisuje trofazni asinhroni motor pogonjen široko usmjerenim sustavom. Tako je za postavljanje sustava potrebno primijeniti matematički model pretvarača (konvertera), modulaciju širine sinusnog impulsa za trofazni izmjenjivač i matematički model trofaznog asinhronog motora. Nakon postavljanja takvog sustava, fokusiraju se PID i regulatori neizrazite logike kako bi se dobili zadovoljavajući rezultati, a to su kratko vrijeme smirivanja brzine rotora, malo harmonijsko i kratko vrijeme smirivanja višefazne struje. Kreirani matematički modeli primijenjeni su na MATLAB Simulinku. Napon istosmjerne struje primijenjen je na ulazu pretvarača. Taj napon je predstavljen obnovljivim izvorom energije koji može biti solarna energija. Napon istosmjerne struje je niži od vršne izmjenične struje. Napon izmjenične struje postiže se iz izlaza izmjenjivača za pogon indukcijskog motora. Najprije se pogone rezistivni (R) i induktivni (L) potrošači. Zatim se pogoni trofazni asinhroni motor (ASM) s istosmjernom strujom niskog napona. Nakon toga, daju se simulacijski rezultati kako bi se pokazao rad i učinkovitost predloženog sustava.

Ključne riječi: izmjenivač (inverter); mikroregulator; modulacija širine impulsa; neizrazita (fuzzy) logika; PID (proporcionalan-integralan-deriviran)

\section{Introduction}

Today, agricultural and industrial activities are done in a wide range area. So, agricultural work in remote areas of the settlements can be performed. Although those areas are distant from energy, three-phase motors have to be used for irrigation operations. Therefore, energy is needed.

There are damages such as gas emissions and harmful waste when traditional electricity generation methods are used in order to provide the energy needs [1]. Solar energy can be utilized to overcome these damages and get rid of problems such as lack of power lines.

Low direct voltage is increased after the voltage is obtained from the solar panel. Then, the direct voltage must be converted into alternating voltage. Usages of power electronics circuits to overcome this situation would be a good choice. For example, inverters are equipment for motor drivers, in computer systems. Therefore, the inverters are widely used for asynchronous machines as power electronic circuits (see $[1 \div 3]$ ). Threephase inverter controlled by using pulse width modulation technique is a common practice in [4] and [5]. However, parameters of asynchronous machines depend on the frequency and operation conditions while asynchronous machines are running. Therefore, these parameters show changes on time. It is difficult to achieve a good working performance on fixed source. To overcome such causes, proposed PWM signals are produced by comparing signals of three sinus and two triangles which have different sizes. Then, PID and fuzzy controllers are applied to the PWM signals in [6] and [7].
The inverter drives three phase machine after low direct voltage is increased to high direct voltage with boost converter. So, system presented in the paper is different from previous studies (see $[8,9]$ ).

The direct voltage is converted to alternating voltage with inverter. Then, three phases of alternating voltage obtained by the inverter are applied to asynchronous machine, resistive $(\mathrm{R})$ and inductive (L) loads at the MATLAB Simulink. There are some articles focusing on PID control and fuzzy logic control systems for inverter circuit $[10 \div 15]$. Fuzzy controller is a non-linear controller that cannot require mathematical model for design although mathematical model of PID controller must be formed for design. Therefore, it provides convenience for the control of complex systems. Because of this reason, fuzzy logic controller is used for the described system in the study. While the system is performed, uncontrolled system is compared to fuzzy logic controlling system and PID controlling system at the MATLAB Simulink. Obtained results of the fuzzy logic controlling system and PID controlling system are more satisfactory than results of uncontrolled system. When fuzzy controlling system is compared to PID controlling and uncontrolled systems, it gives optimal results.

\section{Fuzzy-controlling three-phase inverter fed by DC converter circuit}

The block diagram of system used in this work is given in Fig. 1. DC-DC boost converter is used for three phase inverter input. So, the study is different from other studies (see $[16 \div 18]$ ). 


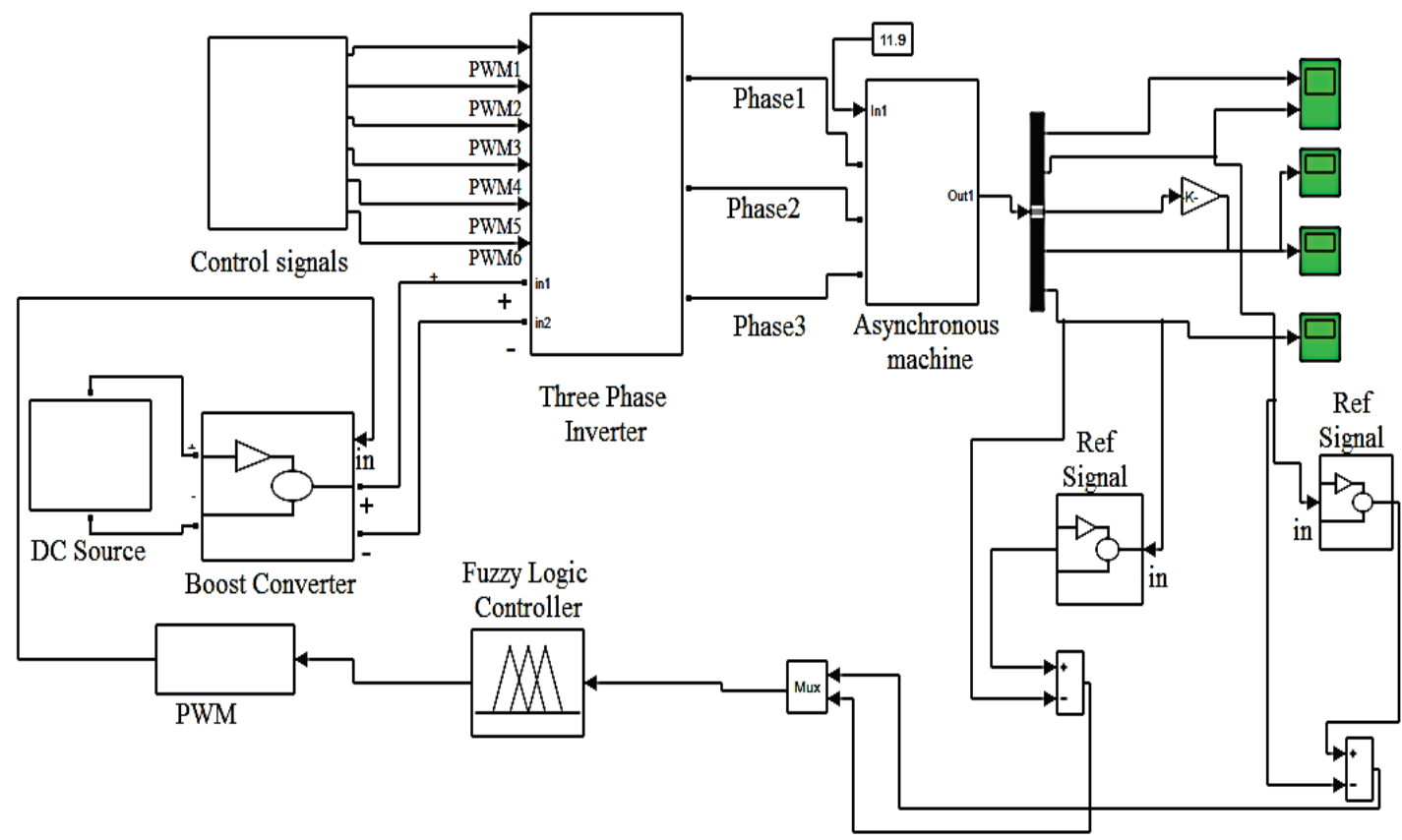

Figure 1 Fuzzy controlling three-phase inverter is running induction motor at the MATLAB Simulink

\subsection{Boost converter circuit design}

The boost converter is used so that $100 \mathrm{~V}$ can be increased to $380 \mathrm{~V}$ as in Fig. 2 (see [16, 17]). Firstly, the converter circuit mathematical model is demonstrated for the relationship between equations of input and output voltages. In the equations, $V_{\mathrm{g}}$ is input voltage, $V_{\mathrm{L}}$ is inductance voltage, and $i_{\mathrm{L}}$ is inductance current, $R$ is resistive load, $C$ is capacitor for converter output voltage and $D$ is duty time for switches.

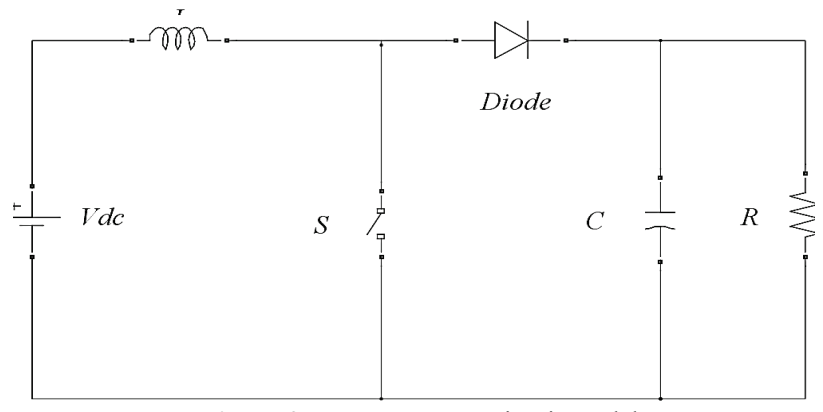

Figure 2 Boost converter circuit model

General equations of the converter are calculated as given below.

$V_{\mathrm{g}}=V_{\mathrm{L}}$,

$\frac{\mathrm{d} i_{\mathrm{L}}}{\mathrm{d} t} L=V_{\mathrm{g}}$,

$\frac{\mathrm{d} i_{\mathrm{L}}}{\mathrm{d} t}=\frac{V_{\mathrm{g}}}{L}$,

$I_{\max }-I_{\min }=\frac{V_{\mathrm{g}}}{L} D T$,

$V_{\mathrm{g}}=V_{\mathrm{L}}+V_{\mathrm{c}}$,

$\frac{\mathrm{d} i_{\mathrm{L}}}{\mathrm{d} t} L=V_{\mathrm{g}}-V_{\mathrm{c}}$, $\frac{\mathrm{d} i_{\mathrm{L}}}{\mathrm{d} t}=\frac{V_{\mathrm{g}}-V_{\mathrm{c}}}{L}$,

$I_{\min }-I_{\max }=\frac{V_{\mathrm{g}}-V_{\mathrm{c}}}{L}(1-D) T$,

$\frac{V_{\mathrm{g}}-V_{\mathrm{c}}}{L}(1-D) T=-\frac{V_{\mathrm{g}}}{L} D T$,

$V_{\mathrm{c}}=\frac{V_{\mathrm{g}}}{1-D}$.

The equations of inductance current and output voltage have to be formed as $\dot{x}=A x+B u$ for state space.

For $S=O N$

$V_{\mathrm{g}}=V_{\mathrm{L}}$,

$\frac{\mathrm{d} i_{\mathrm{L}}}{\mathrm{d} t} L=V_{\mathrm{g}}$,

$i_{\mathrm{L}}=\frac{V_{\mathrm{g}}}{L}$,

$\dot{V}=\frac{I_{\mathrm{Z}}}{C}$.

Variables obtained in the above equations are shown in matrix form as Eq. (15).

$\left[\begin{array}{c}i \\ \dot{V}\end{array}\right]=\left[\begin{array}{cc}0 & 0 \\ 0 & 0\end{array}\right] \cdot\left[\begin{array}{c}I \\ V\end{array}\right]+\left[\begin{array}{cc}\frac{D}{L} & 0 \\ 0 & \frac{D}{C}\end{array}\right] \cdot\left[\begin{array}{c}V_{\mathrm{g}} \\ I_{\mathrm{Z}}\end{array}\right]$.

For $S=O F F$

$V_{\mathrm{g}}=V_{\mathrm{L}}+V_{\mathrm{c}}$,

$\frac{\mathrm{d} i_{\mathrm{L}}}{\mathrm{d} t} L=V_{\mathrm{g}}-V_{\mathrm{c}}$, 
$\frac{\mathrm{d} i_{\mathrm{L}}}{\mathrm{d} t}=\frac{V_{\mathrm{g}}-V_{\mathrm{c}}}{L}$,

$i=\frac{V_{\mathrm{g}}}{L}-\frac{V_{\mathrm{c}}}{L}$,

$\dot{V}=\left(I-\frac{V}{R}+I_{\mathrm{Z}}\right) \cdot \frac{1}{C}$,

$\dot{V}=\frac{I}{C}-\frac{V}{R C}+\frac{I_{\mathrm{Z}}}{C}$.

The equations obtained according to open switch are expressed in matrix form as Eq. (22).

$\left[\begin{array}{c}i \\ \dot{V}\end{array}\right]=\left[\begin{array}{cc}0 & -\frac{1}{C} \\ \frac{1}{C} & -\frac{1}{R C}\end{array}\right] \cdot\left[\begin{array}{c}I \\ V\end{array}\right]+\left[\begin{array}{cc}0 & 0 \\ 0 & \frac{1}{C}\end{array}\right] \cdot\left[\begin{array}{c}V_{\mathrm{g}} \\ I_{\mathrm{Z}}\end{array}\right]$.

$A$ and $B$ are created to form a common state space equation which has variables for converter circuit as given in Eq. (23) and Eq. (24).

$$
\begin{aligned}
& A=D A_{\text {on }}+(1-D) A_{\text {off }}, \\
& B=D B_{\text {on }}+(1-D) B_{\text {off }}
\end{aligned}
$$

Finally matrix form is given as Eq. (25).

$$
A=(D-1)\left[\begin{array}{cc}
0 & -\frac{1}{L} \\
-\frac{1}{C} & -\frac{1}{R C}
\end{array}\right], B=\left[\begin{array}{cc}
\frac{D}{L} & 0 \\
0 & \frac{1}{C}
\end{array}\right] .
$$

\subsection{Three phase inverter circuit}

The study has described the converter which increases low direct voltage. Asynchronous machine and $R, L$ loads are run with direct voltage obtained from output of converter. Therefore, the direct voltage has to be converted into alternating voltage. The results of the works done show that the use of switching function content inverter model has provided understanding of mode of operation system and improving system running in [4] and [5]. Therefore, the three-phase inverter is used for converting alternating voltage in the study. Three-phase inverter circuit has six MOSFET.

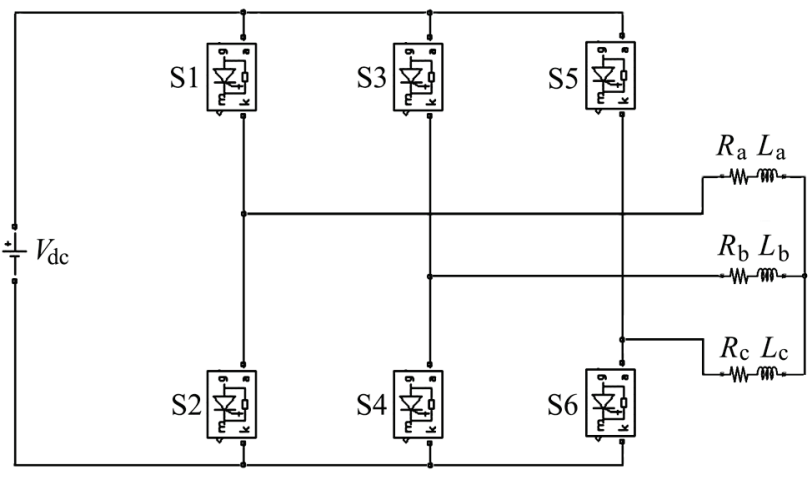

Figure 3 Three phase inverter
These MOSFETs are operated in different groups six times in succession. Therefore, sinus waves are created with $60^{\circ}$ operating angles of MOSFETs. Then, mathematical model of inverter is designed for $R, L$ loads. The three-phase voltage inverter system is showed in Fig. 3. The internal resistance of the system is seen as $R_{\mathrm{a}}, R_{\mathrm{b}}$ and $R_{\mathrm{c}} . L_{\mathrm{a}}, L_{\mathrm{b}}$ and $L_{\mathrm{c}}$ are the inductances. Every phase of the inverter has $R$ and $L . i_{\mathrm{a}}, i_{\mathrm{b}}$ and $i_{\mathrm{c}}$ are the phase currents of the inverter loads. Phase voltages and line voltages are created after three phase inverter is run for $360^{\circ}$.

The switching position of three-phase voltage source

\begin{tabular}{|c|c|c|}
\hline Degree & S--ON & S--OFF \\
\hline $0 \div 60$ & $\mathrm{~S} 1, \mathrm{~S} 3, \mathrm{~S} 6$ & $\mathrm{~S} 2, \mathrm{~S} 4, \mathrm{~S} 5$ \\
\hline $60 \div 120$ & $\mathrm{~S} 2, \mathrm{~S} 3, \mathrm{~S} 6$ & $\mathrm{~S} 1, \mathrm{~S} 4, \mathrm{~S} 5$ \\
\hline $120 \div 180$ & $\mathrm{~S} 2, \mathrm{~S} 3, \mathrm{~S} 5$ & $\mathrm{~S} 1, \mathrm{~S} 4, \mathrm{~S} 6$ \\
\hline $180 \div 240$ & $\mathrm{~S} 2, \mathrm{~S} 4, \mathrm{~S} 5$ & $\mathrm{~S} 1, \mathrm{~S} 3, \mathrm{~S} 6$ \\
\hline $240 \div 300$ & $\mathrm{~S} 1, \mathrm{~S} 4, \mathrm{~S} 5$ & $\mathrm{~S} 2, \mathrm{~S} 3, \mathrm{~S} 6$ \\
\hline $300 \div 360$ & $\mathrm{~S} 1, \mathrm{~S} 4, \mathrm{~S} 6$ & $\mathrm{~S} 2, \mathrm{~S} 3, \mathrm{~S} 5$ \\
\hline
\end{tabular}
inverter system is showed in Tab. 1

Table1 Switching position

Three phase sinus waves are compared to two different triangle signals for PWM s which operate switch group with difference of degree on phase. Comparison of triangular signal and sinus signals for PWM are showed in Fig. 4.

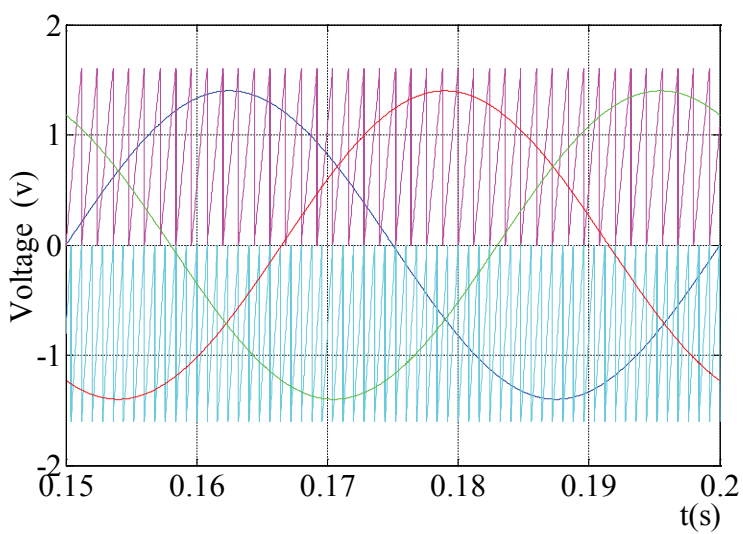

Figure 4 Comparison of triangular signal and sinus signals for PWM

After comparison of signals, PWMs are produced as given in Fig. 5.

If mathematical equations are formed for $0 \div 60$ degree switching time, S1-S3-S6 are ON and S2-S4-S5 are OFF. When mathematical equations are formed for $0-120$ degree switching time, S2-S3-S6 are ON and S1-S4-S5 are OFF. Differential equation is created by the current and voltage equations as Eq. (26).

$\frac{\mathrm{d} i_{\mathrm{a}}}{\mathrm{d} t} L_{\mathrm{a}}+i_{\mathrm{a}} R_{\mathrm{a}}=V_{\mathrm{a}}=V_{\mathrm{c}} \cong \frac{2}{3}\left(\frac{V_{\mathrm{g}}}{1-D}\right)$.

If mathematical equations are formed for 60-120 degree switching time, S2-S3-S6 are ON and S1-S4-S5 are OFF. If mathematical equations are formed for 120180 degree switching time, S2-S3-S5 are ON and S1-S4S6 are OFF. Differential equation is obtained by using the current and voltage equations as given in Eq. (27). 


$$
\frac{\mathrm{d} i_{\mathrm{b}}}{\mathrm{d} t} L_{\mathrm{b}}+i_{\mathrm{b}} R_{\mathrm{b}}=V_{\mathrm{b}}=V_{\mathrm{c}} \cong \frac{2}{3}\left(\frac{V_{\mathrm{g}}}{1-D}\right) .
$$

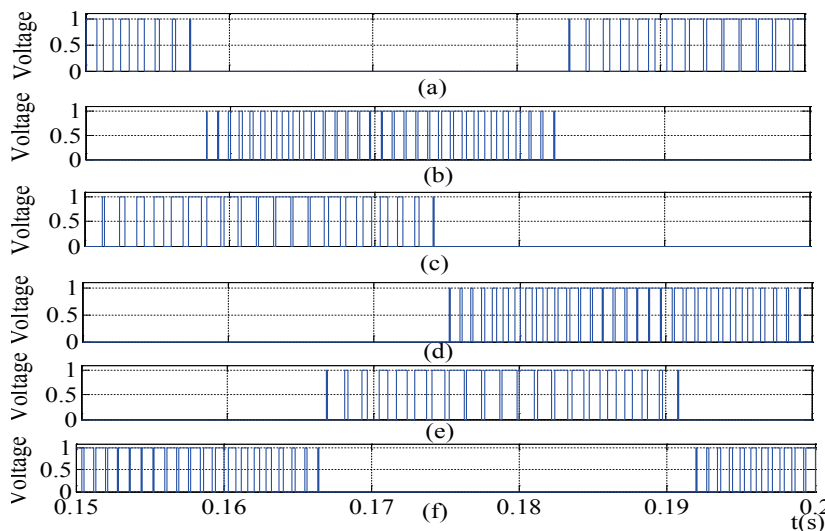

Figure 5 (a) PWM for S1, (b) PWM for S2, (c) S3 for PWM, (b) PWM for S4, (e) PWM for S5, (f) PWM for S6

If mathematical equations are formed for 120-180 degree switching time, S1-S4-S5 are ON and S2-S3-S6 are OFF. If mathematical equations are formed for 180240 degree switching time, S1-S4-S6 are ON and S2-S3$\mathrm{S} 5$ are OFF. Differential equation is created by using the current and voltage equations as given Eq. (28)

$$
\frac{\mathrm{d} i_{\mathrm{c}}}{\mathrm{d} t} L_{\mathrm{c}}+i_{\mathrm{c}} R_{\mathrm{c}}=V_{\mathrm{c}} \cong \frac{2}{3}\left(\frac{V_{\mathrm{g}}}{1-D}\right) .
$$

Matrix form is created by Eq. (26), Eq. (27), and Eq. (28) as Eq. (29).

$$
\left[\begin{array}{c}
\frac{\mathrm{d} i_{\mathrm{a}}}{\mathrm{d} t} \\
\frac{\mathrm{d} i_{\mathrm{b}}}{\mathrm{d} t} \\
\frac{\mathrm{d} i_{\mathrm{c}}}{\mathrm{d} t}
\end{array}\right]=\left[\begin{array}{ccc}
-\frac{R_{\mathrm{a}}}{L_{\mathrm{a}}} & 0 & 0 \\
0 & -\frac{R_{\mathrm{b}}}{L_{\mathrm{b}}} & 0 \\
0 & 0 & -\frac{R_{\mathrm{c}}}{L_{\mathrm{c}}}
\end{array}\right] \cdot\left[\begin{array}{c}
i_{\mathrm{a}} \\
i_{\mathrm{b}} \\
i_{\mathrm{c}}
\end{array}\right]+\left[\begin{array}{c}
V_{\mathrm{a}} \\
V_{\mathrm{b}} \\
V_{\mathrm{c}}
\end{array}\right] .
$$

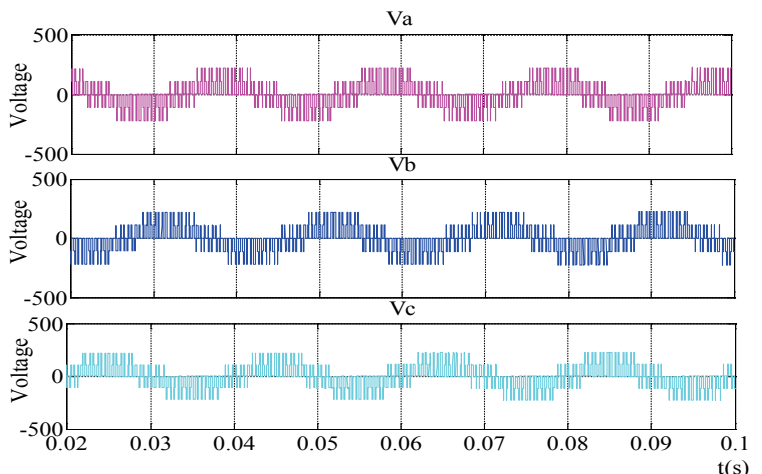

Figure 6 Phase to phase voltages of DC converter connected three phase inverter

After running system at the MATLAB Simulink, alternating voltages of loads are obtained as shown in Fig. 6. Alternating currents of loads are obtained as shown in Fig. 7.

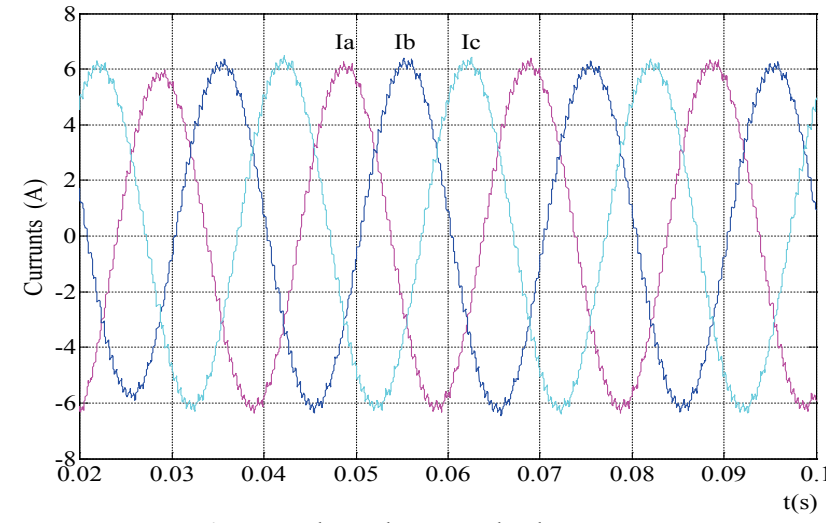

Figure 7 Three phase $R, L$ load currents

\subsection{Induction motor}

In section 2, steady state equations of the inverter with $R, L$ loads have been established for star connected and balanced loads. In addition, MATLAB Simulink using mathematical model of induction motor is established. So, these mathematical models are constructed with considering alpha axis and beta axis representing the equivalent circuits. Alpha axis representing the equivalent circuit is given as in Fig. 8 . Beta axis representing the equivalent circuit is given as Fig. 9.

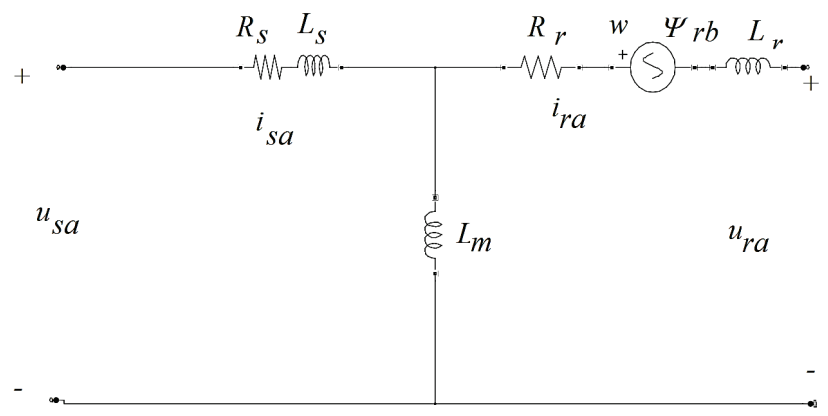

Figure 8 Alpha-axis equivalent circuit of induction motor

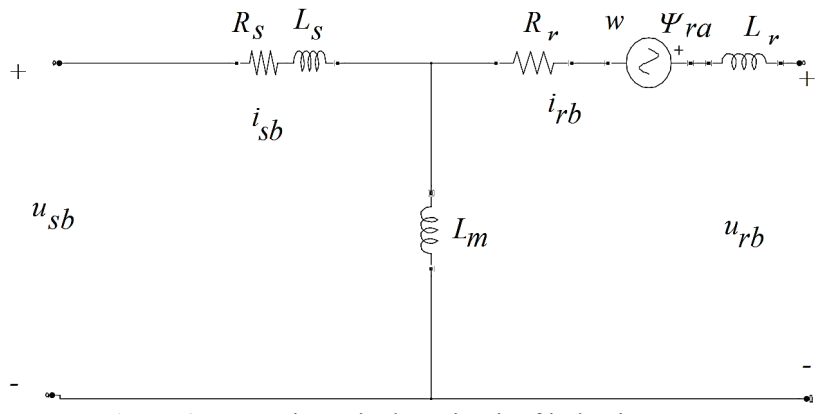

Figure 9 Beta-axis equivalent circuit of induction motor

$R_{\mathrm{S}}$ is stator resistance, $L_{\mathrm{m}}$ is magnetizing inductance, $L_{\mathrm{S}}$ is stator inductance, $R_{\mathrm{r}}$ is rotor resistance, $L_{\mathrm{r}}$ is rotor inductance, $J$ is load inertia coefficient, $T_{\mathrm{e}}$ is electromagnetic torque, $T_{\mathrm{L}}$ is mechanical shaft torque, $W_{\mathrm{m}}$ is angular velocity of the rotor, $W_{\mathrm{r}}$ is electrical angular velocity, $B$ is load viscous friction coefficient, $\mathrm{p}$ is the number of pole pairs. $\Psi_{\mathrm{sa}}$ is stator alpha flux, $\Psi_{\mathrm{sb}}$ is stator beta flux, $\Psi_{\mathrm{ra}}$ is rotor alpha flux, $\Psi_{\mathrm{rb}}$ is rotor beta flux, $u_{\mathrm{sa}}$ is alpha axis stator voltage, $u_{\mathrm{sb}}$ is beta axis stator voltage, $u_{\mathrm{ra}}$ is alpha axis rotor voltage, $u_{\mathrm{rb}}$ is beta axis rotor 
voltage, $i_{\mathrm{sb}}$ is stator beta current, $i_{\mathrm{sa}}$ is stator alpha current, $i_{\mathrm{rb}}$ is rotor beta current and $i_{\mathrm{ra}}$ is rotor alpha current.

When equations of the stator flux and the rotor flux are generated for the alpha and beta axes, the following equations are obtained.

$\Psi_{\mathrm{sa}}=L_{\mathrm{s}} i_{\mathrm{sa}}+L_{\mathrm{m}} i_{\mathrm{ra}}$

$\Psi_{\mathrm{sb}}=L_{\mathrm{s}} i_{\mathrm{sb}}+L_{\mathrm{m}} i_{\mathrm{rb}}$

$\Psi_{\mathrm{ra}}=L_{\mathrm{r}} i_{\mathrm{ra}}+L_{\mathrm{m}} i_{\mathrm{sa}}$,

$\Psi_{\mathrm{rb}}=L_{\mathrm{r}} i_{\mathrm{rb}}+L_{\mathrm{m}} i_{\mathrm{sb}}$

When equations of the stator voltage and the rotor voltage are generated for the alpha axis and the beta axis, the following equations are obtained.

$u_{\mathrm{sa}}=R_{\mathrm{s}} i_{\mathrm{sa}}+\frac{\mathrm{d}}{\mathrm{d} t} \Psi_{\mathrm{sa}}$,

$u_{\mathrm{sb}}=R_{\mathrm{s}} i_{\mathrm{sb}}+\frac{\mathrm{d}}{\mathrm{d} t} \Psi_{\mathrm{sb}}$,

$u_{\mathrm{ra}}=R_{\mathrm{r}} i_{\mathrm{ra}}+\frac{\mathrm{d}}{\mathrm{d} t} \Psi_{\mathrm{ra}}+w \Psi_{\mathrm{sb}}$,

$u_{\mathrm{rb}}=R_{\mathrm{r}} i_{\mathrm{rb}}+\frac{\mathrm{d}}{\mathrm{d} t} \Psi_{\mathrm{rb}}-w \Psi_{\mathrm{ra}}$.

The equation of the stator alpha-axis current is formed as Eq. (41).

$$
\begin{aligned}
& u_{\mathrm{sa}}=R_{\mathrm{s}} i_{\mathrm{sa}}+\frac{\mathrm{d}}{\mathrm{d} t} L_{\mathrm{s}} i_{\mathrm{sa}}+\frac{\mathrm{d}}{\mathrm{d} t} \frac{L_{\mathrm{m}} \Psi_{\mathrm{ra}}}{L_{\mathrm{r}}}-\frac{\mathrm{d}}{\mathrm{d} t} \frac{L_{\mathrm{m}}^{2} i_{\mathrm{sa}}}{L_{\mathrm{r}}}, \\
& u_{\mathrm{sa}}=R_{\mathrm{s}} i_{\mathrm{sa}}+\frac{\mathrm{d}}{\mathrm{d} t} i_{\mathrm{sa}}\left(L_{\mathrm{s}}-\frac{L_{\mathrm{m}}^{2}}{L_{\mathrm{r}}}\right)+\frac{\mathrm{d}}{\mathrm{d} t} \frac{L_{\mathrm{m}} \Psi_{\mathrm{ra}}}{L_{\mathrm{r}}}, \\
& u_{\mathrm{sa}}=R_{\mathrm{s}} i_{\mathrm{sa}}+\frac{\mathrm{d}}{\mathrm{d} t} i_{\mathrm{sa}}\left(\frac{L_{\mathrm{s}} L_{\mathrm{r}}-L_{\mathrm{m}}^{2}}{L_{\mathrm{s}} L_{\mathrm{r}}}\right) L_{\mathrm{s}}+\frac{\mathrm{d}}{\mathrm{d} t} \frac{L_{\mathrm{m}} \Psi_{\mathrm{ra}}}{L_{\mathrm{r}}}, \\
& \left(u_{\mathrm{sa}}-\frac{\mathrm{d}}{\mathrm{d} t} \Psi_{\mathrm{ra}} \frac{L_{\mathrm{m}}}{L_{\mathrm{r}}}-R_{\mathrm{s}} i_{\mathrm{sa}}\right) \frac{1}{\sigma L_{\mathrm{s}}}=\frac{\mathrm{d}}{\mathrm{d} t} i_{\mathrm{sa}} .
\end{aligned}
$$

The equation of the beta-axis stator current is formed as Eq. (45).

$$
\begin{aligned}
& u_{\mathrm{sb}}=R_{\mathrm{s}} i_{\mathrm{sb}}+\frac{\mathrm{d}}{\mathrm{d} t} L_{\mathrm{s}} i_{\mathrm{sb}}+\frac{\mathrm{d}}{\mathrm{d} t} L_{\mathrm{m}} \frac{\Psi_{\mathrm{rb}}-L_{\mathrm{m}} i_{\mathrm{sb}}}{L_{\mathrm{r}}} \\
& u_{\mathrm{sb}}=R_{\mathrm{r}} i_{\mathrm{sb}}+\frac{\mathrm{d}}{\mathrm{d} t} L_{\mathrm{s}} i_{\mathrm{sb}}+\frac{\mathrm{d}}{\mathrm{d} t} \frac{L_{\mathrm{m}} \Psi_{\mathrm{rb}}}{L_{\mathrm{r}}}-\frac{\mathrm{d}}{\mathrm{d} t} \frac{L_{\mathrm{m}}^{2} i_{\mathrm{sb}}}{L_{\mathrm{r}}} \\
& u_{\mathrm{sa}}=R_{\mathrm{s}} i_{\mathrm{sb}}+\frac{\mathrm{d}}{\mathrm{d} t} i_{\mathrm{sb}}\left(\frac{L_{\mathrm{s}} L_{\mathrm{r}}-L_{\mathrm{m}}^{2}}{L_{\mathrm{s}} L_{\mathrm{r}}}\right) L_{\mathrm{s}}+\frac{\mathrm{d}}{\mathrm{d} t} \frac{L_{\mathrm{m}} \Psi_{\mathrm{rb}}}{L_{\mathrm{r}}} \\
& \left(u_{\mathrm{sb}}-\frac{\mathrm{d}}{\mathrm{d} t} \Psi_{\mathrm{rb}} \frac{L_{\mathrm{m}}}{L_{\mathrm{r}}}-R_{\mathrm{s}} i_{\mathrm{sb}}\right) \frac{1}{\sigma L_{\mathrm{s}}}=\frac{\mathrm{d}}{\mathrm{d} t} i_{\mathrm{sb}} \\
& \sigma=\frac{L_{\mathrm{s}} L_{\mathrm{r}}-L_{\mathrm{m}}^{2}}{L_{\mathrm{s}} L_{\mathrm{r}}}
\end{aligned}
$$

Torque equations are given as follows:

$$
\begin{aligned}
& T_{\mathrm{e}}=\frac{3}{2} p L_{\mathrm{m}}\left(i_{\mathrm{sb}} i_{\mathrm{ra}}-i_{\mathrm{sa}} i_{\mathrm{rb}}\right), \\
& J \frac{\mathrm{d} w_{\mathrm{m}}}{\mathrm{d} t}=T_{\mathrm{e}}-T_{\mathrm{L}}-B w_{\mathrm{m}}, \\
& \frac{2}{p} w_{\mathrm{r}}=w_{\mathrm{m}} .
\end{aligned}
$$

PID control is done in order to get a better result from the system. Differential expression of the PID controller equation is Eq. (50). Laplace expression of the PID controller equation is Eq. (51). Where: $K_{\mathrm{p}}$ is proportional gain, $K_{\mathrm{i}}$ is integral gain and $K_{\mathrm{d}}$ is derivation gain.

$$
\begin{aligned}
& u(t)=K_{\mathrm{p}} e(t)+K_{\mathrm{i}} \int e(t) \mathrm{d} t+K_{\mathrm{d}} \frac{\mathrm{d} e}{\mathrm{~d} t}, \\
& K_{\mathrm{p}}+\frac{K_{\mathrm{i}}}{s}+K_{\mathrm{d}} s=\frac{K_{\mathrm{p}} s^{2}+K_{\mathrm{p}} s+K_{\mathrm{i}}}{s} .
\end{aligned}
$$

After the system of PID control, applications of fuzzy logic controlling circuits have been reported for several researchers as in [12] and [13]. So, fuzzy controller is designed to get better results in the study. Some logical condition must be understood to design a fuzzy logic controller. $d u$ is generated from input values of the control error $(e)$ and change of control error $(d e)$.

The error $(e)$ is obtained from reference signal $r(k)$ and output signal $y(k)$. The equation of error is given in Eq. (52). Change of error is the difference between two errors in succession. The error of change is as in Eq. (53). Three or five triangles can be used if the fuzzy logic

\begin{tabular}{|c|c|c|c|c|c|c|}
\hline & \multicolumn{5}{|c|}{$(d e)$} \\
\hline & & NB & NS & $\mathrm{ZZ}$ & PS & $\mathrm{PB}$ \\
\hline \multirow{5}{*}{$(e)$} & PB & $\mathrm{ZZ}$ & PS & PS & PB & $\mathrm{PB}$ \\
\hline & PS & NS & $\mathrm{ZZ}$ & PS & PS & PB \\
\hline & $\mathrm{ZZ}$ & NS & NS & $\mathrm{ZZ}$ & PS & PS \\
\hline & NS & NB & NS & NS & $\mathrm{ZZ}$ & PS \\
\hline & NB & NB & NB & NS & NS & $\mathrm{ZZ}$ \\
\hline
\end{tabular}
membership will be created. $\mathrm{N}$ is Negative, $\mathrm{Z}$ is zero, $\mathrm{P}$ is positive can be defined from the membership of three triangles. NB is negative big, NS is negative small, $\mathrm{Z}$ : zero, PS: positive small, PB: positive big can be defined for the membership of five triangles. Interaction results in the formation of the membership create the output values of (du) which are shown in Tab. 2 and in Tab. 3.

$$
\begin{aligned}
& e(k)=r(k)-y(k), \\
& d e(k)=e(k)-e(k-1) .
\end{aligned}
$$

Table 2 Three section fuzzy rule decision table

\begin{tabular}{|c|c|c|c|c|}
\hline \multicolumn{2}{|c|}{} & \multicolumn{3}{|c|}{$(d e)$} \\
\cline { 3 - 5 } \multicolumn{2}{|c|}{} & $\mathrm{N}$ & $\mathrm{Z}$ & $\mathrm{P}$ \\
\hline \multirow{3}{*}{$(e) \quad$} & $\mathrm{N}$ & $\mathrm{N}$ & $\mathrm{N}$ & $\mathrm{N}$ \\
\cline { 2 - 5 } & $\mathrm{Z}$ & $\mathrm{N}$ & $\mathrm{Z}$ & $\mathrm{P}$ \\
\cline { 2 - 5 } & $\mathrm{P}$ & $\mathrm{P}$ & $\mathrm{P}$ & $\mathrm{P}$ \\
\hline \multicolumn{3}{|c|}{$(d u)$} \\
\hline
\end{tabular}

Table 3 Five section fuzzy rule decision table

If the error $(k-1)$ value as seen in Fig. 12 is larger than error value $k$, error is a positive value. Therefore, the 
change of error (de) moves to reduce in negative direction. If error is $(k+a)$ as given in Fig. 12, the error is negative for reference value. The error increases in negative direction as maximum.
Interactions of rules are given on three section fuzzy rule decision values as given in Tab. 2. Interactions of rules are given on five section fuzzy rule decision values as given in Tab. 3 .

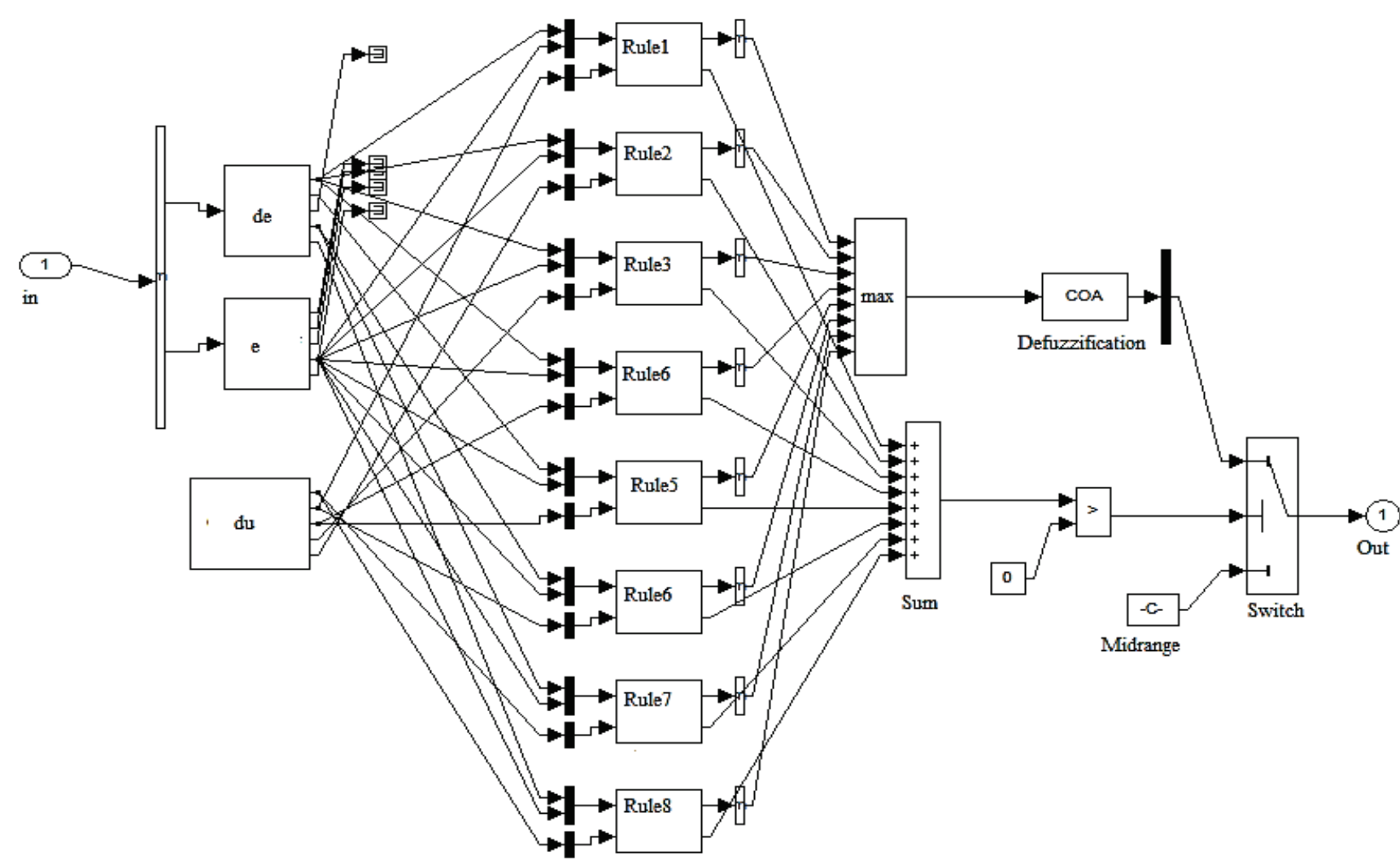

Figure 10 The input and output units of the fuzzy logic controller
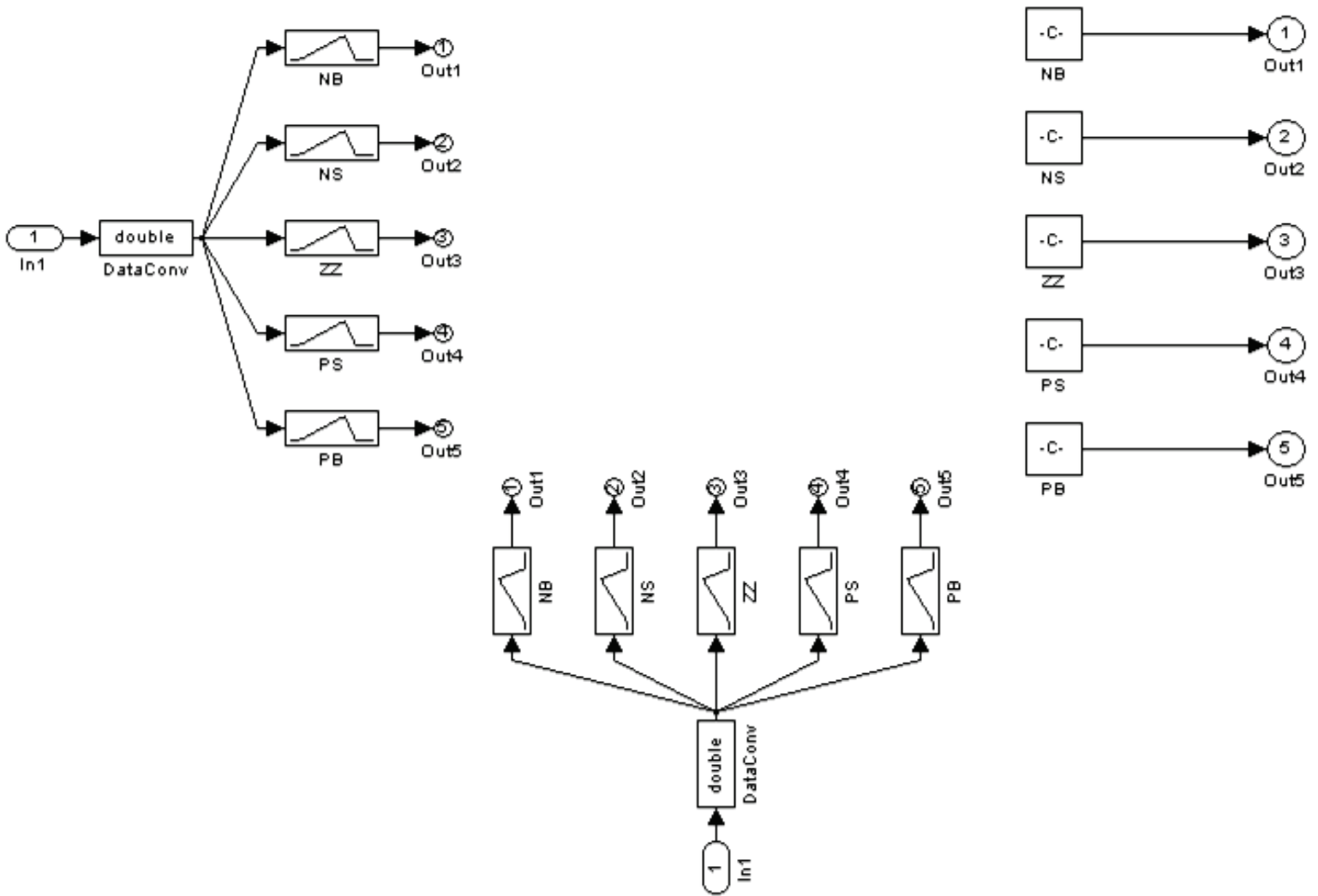

Figure 11 Values of de and e intersection for du at the MATLAB Simulink 
Defuzzification operation is performed as in the following Eq. (54).

$d u_{R}(k)=\frac{\sum_{i=8,9,13,14} \mu_{R_{i}}\left(d u_{R}\right)\left(R_{i}\right)}{\sum_{i=1}^{4} \mu_{i}\left(u V_{R}\right)}$.

Fuzzy control unit of system has position of triangle membership for output $(d u)$ at the MATLAB Simulink as in Fig. 10. Interaction of rules between $(d e)$ and $(e)$ for $d u$ are shown as in Fig. 11. Finally, fuzzy controlling threephase inverter fed by dc converter circuit is run induction motor at the MATLAB Simulink as shown in Fig. 1.
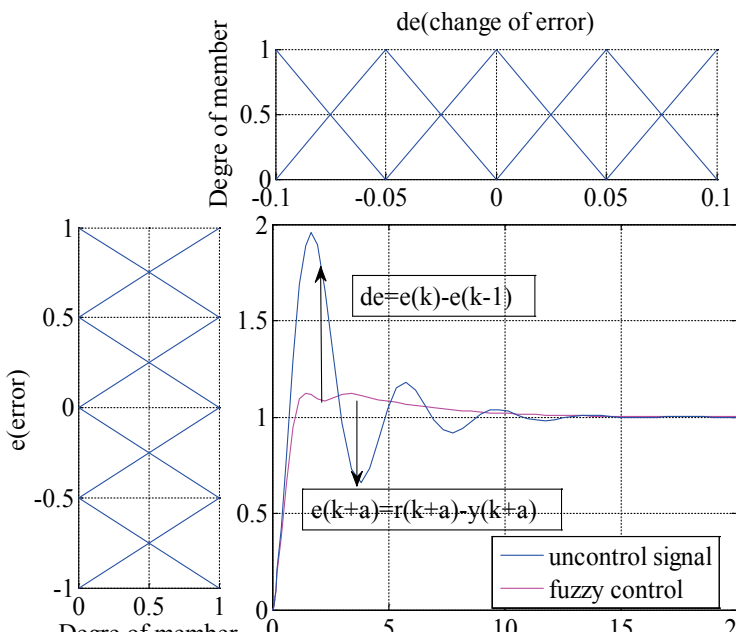

Degre of member

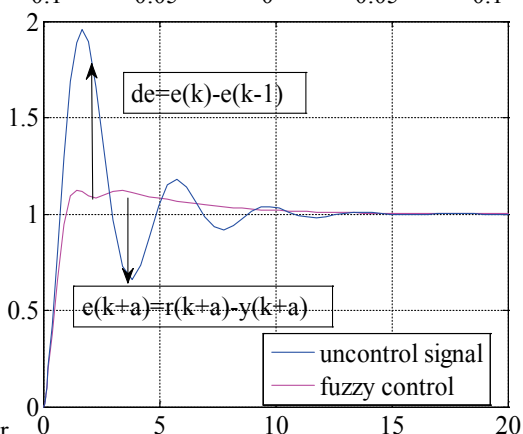

Figure 12 Error and change of error at the signal

\subsection{Experimental results for induction motor}

Rotor speed of PID controlling system is $1720 \mathrm{rpm}$ for $0,5 \mathrm{~s}$ while rotor speed of uncontrolled system is 1720 $\mathrm{rpm}$ at $0,6 \mathrm{~s}$. Rotor speed of fuzzy logic controlling system is $1720 \mathrm{rpm}$ for $0,3 \mathrm{~s}$. Therefore, accelerating time and rotor speed settling time of fuzzy controlling machine are shorter than settling time of PID controlling machine and settling time of uncontrolled machine. Rotor speed settling time of PID controlling system is shorter than rotor speed settling time of uncontrolled system. These results are shown as in Fig. 13.

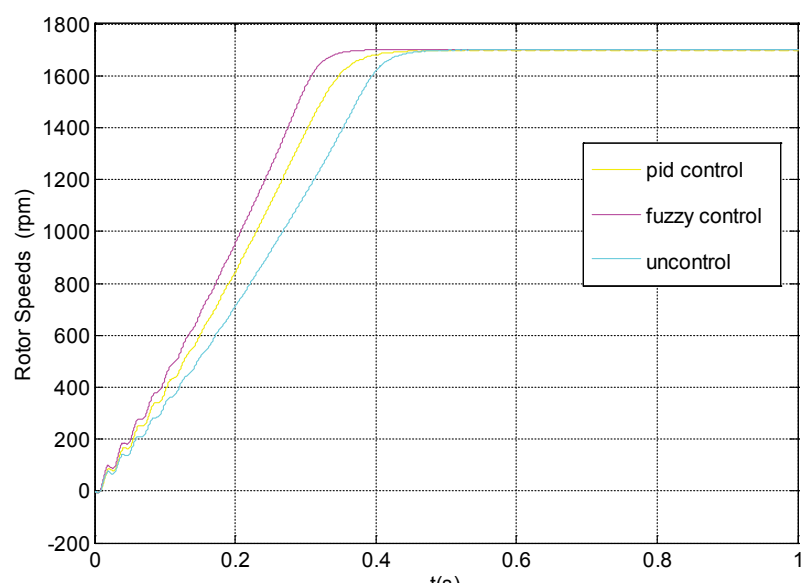

Figure 13 Rotor speeds of three phase asynchronous machine (ASM)
Torque settling of fuzzy controlling machine is shorter than torque settling of PID controlling machine and torque settling of uncontrolled machine on time. Fuzzy controlling machine has lower distortion than PID controlling machine and uncontrolled machine for torques which are shown as in Fig. 14.

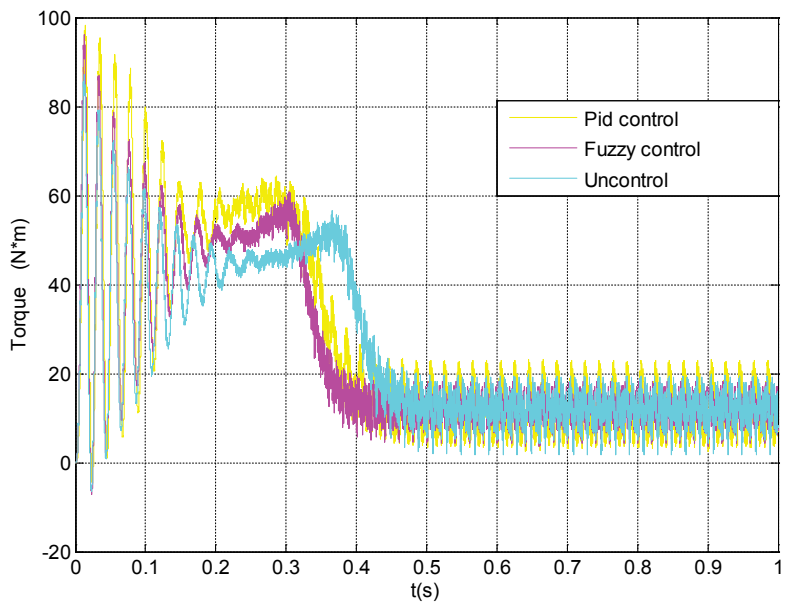

Figure 14 Rotor torque of three phase asynchronous machine (ASM)

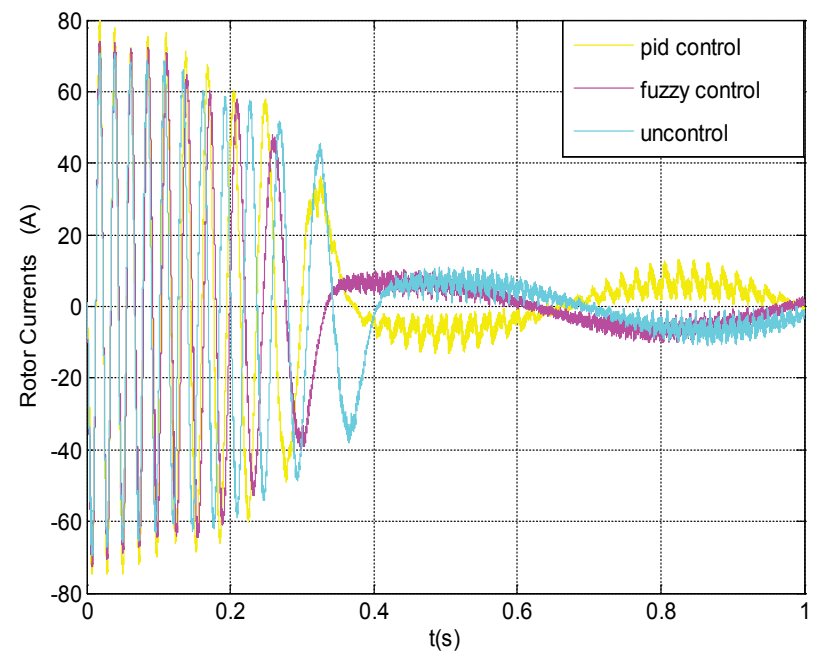

Figure 15 Rotor currents of three phases ASM

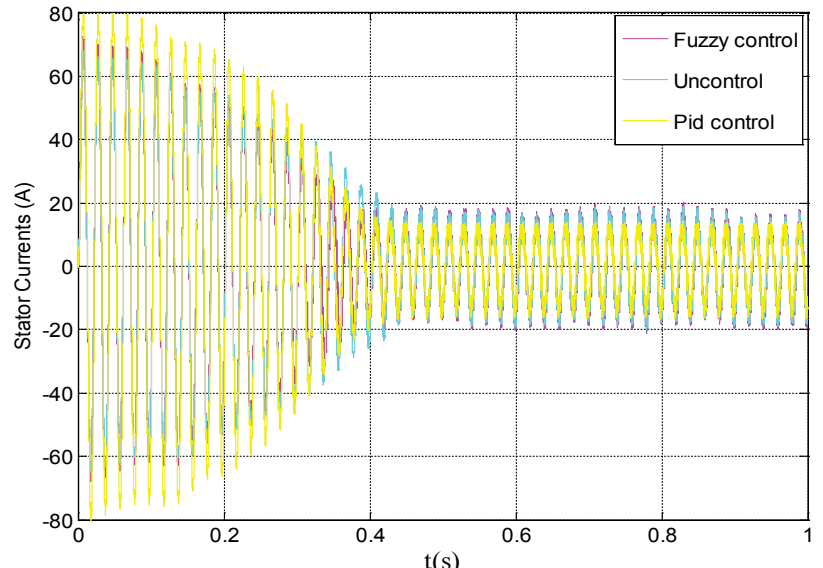

Figure 16 Stator currents of three phase asynchronous machine

Settling time of rotor current is $0,3 \mathrm{~s}$. for fuzzy logic controlling machine while rotor current settling time of PID controlling machine is 0,4 s. Rotor current settling time of Fuzzy controlling machine is shorter than current 
settling times of PID controlling and uncontrolled machines. These currents are shown as in Fig. 15

Stator current settling time of Fuzzy controlling machine is shorter than current settling time of PID controlling and current settling time of uncontrolled machines. These currents are shown as in Fig. 16.

According to experimental results, harmonic distortion of stator current is $1,1 \%$ as shown in Fig. 17.

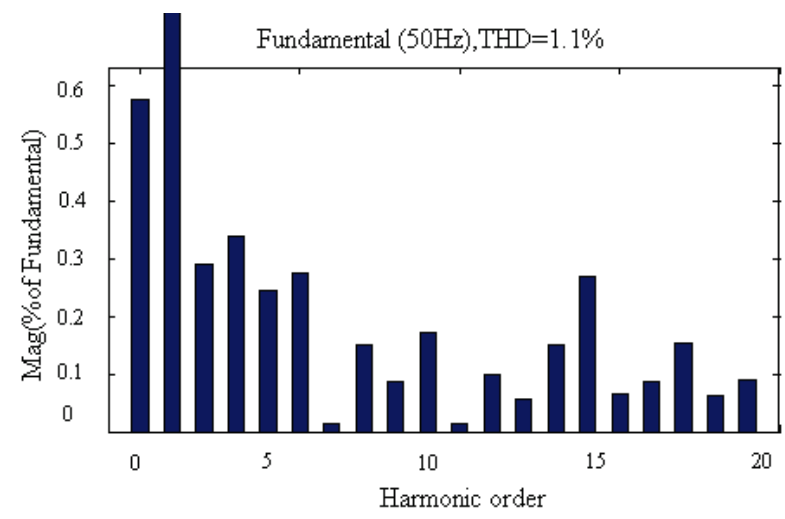

Figure 17 Stator currents harmonic distortion

\section{Conclusion}

In this study, a three phase asynchronous machine driven by a broad-based system is described. Direct voltage is applied to input of converter. The direct voltage is lower than the peak of the alternating voltage. The voltage obtained from output of the inverter runs the induction motor by using fuzzy controller and PID controller. Results of fuzzy logic controlling machine are compared to results of the uncontrolled system and PID system. Then more satisfactory results are observed from fuzzy logic controlling machine. Accelerating time and rotor speed settling time of fuzzy controlling machine are shorter than settling time of PID controlling machine and settling time of uncontrolled machine. PID control settling time is shorter than uncontrolled settling time.

Fuzzy logic controlling system has a low harmonic distortion which is given in Fig. 16. According to observed results, system has been successfully implemented. So, satisfactory results are obtained in the study.

\section{References}

[1] Jung, J.; Nam, K. A dynamic decoupling control scheme for high-speed operation of induction motors. // IEEE Transactions on Industrial Electronics. 46, 1(1999), pp. 100-110. DOI: 10.1109/41.744397

[2] Larsson T.; Edris, A.; Kidd, D.; Aboytes, F. Eagle Pass Back-to-Back Tie: A Dual Purpose Application of Voltage Source Converter Technology. // EEE Power Engineering Society Summer Meeting. 3, (July 2001), pp. 1686-1691. DOI: 10.1109/PESS.2001.970329

[3] Rashid, M. H. Power electronics: circuits, devices and applications. // (Prentice Hall, Englewood Cliffs, NJ, USA, $1993,2^{\text {nd }}$ ed.).

[4] Cheng, C.-H. Design of output filter for inverters using fuzzy logic. // Expert Systems with Applications. 38, 7(2011), pp. 8639-8647. DOI: 10.1016/j.eswa.2011.01.069

[5] Carrasco, J. M.; Franquelo, L. C.; Bialasiewicz, J. T.; Galván, E.; Guisado, R. C. P.; Prats, M. A. M.; León, J. I.;
Moreno-Alfonzo, N. Power-electronic system for the grid integration of renewable energy sources: A survey. // IEEE Trans. Ind. Electron. 53, 4(2006), pp. 1002-1016. DOI: 10.1109/TIE.2006.878356

[6] Su, G. J. Pulse-Width-Modulation Schemes for an Integrated Traction and Compressor Drive System. // 21st Applied Power Electronics Conference and Exposition (APEC'06), vol. 2, (March 19-23, 2006), pp. 640-645. DOI: 10.1109/apec.2006.1620606

[7] Salazar, L.; Joos, G. PSPICE simulation of three-phase inverters by means of switching functions. // IEEE Trans Power Electron. 9, (Jan. 1994), pp. 35-42. DOI: 10.1109/63.285491

[8] Elmas, C.; Deperlioglu, O.; Sayan, H. H. Adaptive fuzzy logic controller for DC-DC converters. // Expert Systems with Applications. 36, (2009), pp. 1540-1548. DOI: 10.1016/j.eswa.2007.11.029

[9] Runghimmawan, T. Design and Implementation Multilevel Inverter for 3 phase Induction Motor Speed Control with RBM Chopper Technique embedded on FPGA. // Power System Technology, PowerCon 2006.

[10] Sarhan H.; Issa, R. Improving Mechanical Characteristics of Inverter-induction Motor Drive System. // Proceedings of American Journal of Applied Sciences. 3, 8(2006), pp. 1961-1966. DOI: 10.3844/ajassp.2006.1961.1966

[11] Enjeti, P. N.; Ziogas, P. D. Analysis of a static power converter under unbalance: A novel approach. // IEEE Trans. Ind. Electron. Vol. 37, (Feb. 1990), pp. 91-93. DOI: 10.1109/41.45849

[12] He, Y.; Luo, F. L. Study of sliding mode control for DCDC converters. // PowerCon 2004, vol. 2, 2004, pp. 1969 1974.

[13] Lin, B.-R. Analysis of Fuzzy Inverter Control. // European Trans. Electrical Power. 5, 4(1995), pp. 235-246. DOI: 10.1002/etep.4450050403

[14] Duan, S.-X.; Kang, Y.; Chen, J. An Algorithm for the Output Waveform Compensation of SPWM Based on Fuzzy-Repetitive Control. // Journal Electrical Eng. 55, (2005), pp. 64-70.

[15] Bay, O. F.; Elmas, C. Modeling of the Inductance Variation and Control of the Switched Reluctance Motor Based on Fuzzy Logic. // Intelligent Automation \& Soft Computing. 10, 3(2004), pp. 233-246. DOI: 10.1080/10798587.2004.10642880

[16] Husodo, B. Y.; Ayob, S. M. Simulation of Modified Simple Boost Control for Z-Source Inverter. // International Journal of Automation and Power Engineering. 2, 4(2013), pp. 5764.

[17] Oshaba, A. S.; Ali, E. S. Swarming Speed Control for DC Permanent Magnet Motor Drive via Pulse width Modulation Technique and DC-DC Converter. // Research Journal of Applied Sciences, Engineering and Technology. 5, 18(2013), pp. 4576-4583.

[18] Dubey, S.; Srivastava, S. K. Speed Control of DC Motor Using Fuzzy Logic Controller. // IJBSTR. 1, 7(2013), pp. 34-38.

\section{Authors' addresses}

Dr. Erol Can

Erzincan University, Vocational High School,

Electronic and Automation Department,

Erzincan, Turkey

E-mail: can e@hotmail.com

\section{H. Hüseyin Sayan}

Gazi University, Faculty of Technology,

Department of Electrical and Electronics Engineering,

Ankara, Turkey

E-mail: hsayan@gazi.edu.tr 